IRSTI $34.15 .25 ; 34.03 .23$

\author{
Yurikova O. ${ }^{1}$, Atambaeva Sh. ${ }^{2}$, Bolshoy A. ${ }^{3}$, Ivashchenko A. ${ }^{4}$ \\ ${ }^{1} \mathrm{PhD}$-student, research assistant, e-mail: oksanayurikova@mail.ru \\ ${ }^{2}$ candidate of biological sciences, associate professor, lead researcher, e-mail: atambayevashara@gmail.com \\ ${ }^{4}$ doctor of biological sciences, professor, chief researcher, e-mail: a_ivashchenko@mail.ru \\ Scientific Research Institute of Biology and Biotechnology Problems, \\ al-Farabi Kazakh National University, Kazakhstan, Almaty \\ ${ }^{3} \mathrm{PhD}$, associate professor, Department of Evolutionary and Environmental Biology, \\ University of Haifa, Israel, Haifa, e-mail: bolshoy@research.haifa.ac.il

\section{MIR-1322 BINDING SITES IN MRNAS OF GENES INVOLVED IN THE DEVELOPMENT OF NEURODEGENERATIVE AND ONCOLOGICAL DISEASES}

Existence of miRNA binding sites in $3^{\prime}-U T R, 5^{\prime}-U T R$ and CDS regions of the mRNA of animal genes is confirmed. The efficiency of miRNA-induced repression increases with the number of sites. The binding of miRNA can be significant if the gene contains repeats of the site sequences in the coding region. It is shown that miR-1322 has polysites in CDS region of mRNAs of dozens of human genes. Experimental verification of functionality of the large number of sites is time-consuming and labor intensive. One of the ways to predict miRNA binding sites is to check the existence of these sites in mRNA of orthologous genes and to analyze their divergence during evolution. The analysis of conservation of miR-1322 polysites in CDS of mRNAs of ATN1, BCL6B, HTT, MAGI1, MLLT3, MN1, THAP11, TBP human genes and their orthologues was carried out. The studied genes are involved in development of neurodegenerative and oncological diseases. The obtained results show that polysites for binding miR-1322 are found in mRNAs of orthologous genes of many animal species. In the process of evolution, the number of binding sites changes, that indicates species dependence of efficiency of regulation of these genes expression by miR-1322. In addition to general contribution to the study of pathogenesis mechanisms caused by participation of ATN1, BCL6B, HTT, MAGI1, MLLT3, MN1, THAP11 and TBP genes our analysis allows to propose an adequate experimental animal model for further study of regulation of described genes expression by miR-1322.

Key words: miR-1322, mRNA, orthologous genes, socially significant diseases.

Юрикова О. ${ }^{1}$, Атамбаева Ш. ${ }^{2}$, Большой А. ${ }^{3}$, Иващенко А. ${ }^{4}$

1PhD-докторантураның студенті, тәжірибе-жинақтаушы, e-mail: oksanayurikova@mail.ru ${ }^{2}$ биология ғылымдарының кандидаты, доцент, жетекші ғылыми қызметкер, e-mail: atambayevashara@gmail.com ${ }^{4}$ биология ғылымдарының докторы, профессор, бас ғылыми қызметкер, e-mail: a_ivashchenko@mail.ru Биология және биотехнология мәселелерін ғылыми-зерттеу институты, әл-Фараби атындағы Қазақ ұлттық университеті, Қазақстан, Алматы қ.

${ }^{3} \mathrm{PhD}$, қауымдастырылған профессор, эволюциялық, және экологиялық, кафедрасы,

Хайфа университеті, Израиль, Хайфа к., e-mail: bolshoy@research.haifa.ac.il

Нейродегенеративті және онкологиямық аурулардың дамуына қатысатын гендерінің mRNA-мен miR-1322 байланысу сайттары

\footnotetext{
Жануарлар гендерінің mRNA-ғы 3'-UTR-де ғана емес, сонымен қатар 5'-UTR және CDS аймақтарында miRNA байланысу сайттары болуы анықталАы. miRNA-ның әсерінен болған репрессиясының тиімділігі байланысу сайттардың санымен көбеюде. Геннің кодтау аймағындағы қайталайтын тізбектері бар болса, miRNA-ның байланысуы жоғары болу мүмкін. Ондаған адам гендердің mRNA-ғы CDS аймақтарында miR-1322-ның полисайттары бар болуы көрсетілген. Көптеген сайттардың функционалдығын эксперименттік тексерісі көп еңбекті болып табылады. miRNA үшін сенімді сайттарын анықтаудың бір жолы - ортологиялық гендердің mRNA-сында
} 
miR-1322 binding sites in mRNAs of genes involved in the development of neurodegenerative and oncological diseases

бұл сайттардың бар екендігін дәлелдеу және эволюция барысында олардың алшақтықтарын та^дау. ATN1, BCL6B, HTT, MAGI1, MLLT3, MN1, THAP11, TBP аАам гендердің және олардың ортологтардың mRNA-ғы CDS аймақтарында miR-1322 полисайттардың консервативтілігінің талдауы жүргізілді. Зерттелген гендер нейродегенеративті және онкологиялық аурулардың дамуына қатысады. Зерттеу нәтижелері көптеген жануарлар түрлерінің ортологиялық гендердің mRNA-да miR-1322 байланысу сайттары бар екенАігін көрсетті. Эволюция барысында, байланысу сайттардың саны өзгереді, бұл өзгерістер осы гендердің miR-1322-мен жүргізілетін экспрессиялық реттеу тиімділігі түрге тәуелді екенін көрсетеді. А^ынған нәтижелер ATN1, BCL6B, HTT, MAGl1, MLLT3, MN1, THAP11 және TBP гендердің қатысуымен пайда болған патогенез механизмдерін зерттеуіне жалпы үлес береді, сонымен қатар, біздің та^дау сипатталған гендердің экспрессиясын миР-1322 арқылы реттеуді одан әрі зерттеу үшін тәжірибелік жануарлардың моделін ұсынуға мүмкіндік береді.

Tүйін сөздер: miR-1322, mRNA, ортологиялық, гендер, әлеуметтік маңызды аурулар.

$$
\begin{aligned}
& \text { Юрикова O. }{ }^{1} \text {, Атамбаева Ш.. }{ }^{2} \text { Большой А. }{ }^{3}, \text { Иващенко А. }{ }^{4} \\
& { }^{1} \text { студент PhD-докторантуры, стажер-исследователь, e-mail: oksanayurikova@mail.ru } \\
& { }^{2} \text { кандидат биологических наук, Аоцент, ведущий научный сотрудник, e-mail: atambayevashara@gmail.com } \\
& { }^{4} \text { Аоктор биологических наук, профессор, главный научный сотрудник, e-mail: a_ivashchenko@mail.ru } \\
& \text { Научно-исследовательский институт проблем биологии и биотехнологии, } \\
& \text { Казахский национальный университет имени аль-Фараби, Казахстан, г. Алматы } \\
& { }^{3} \mathrm{PhD} \text {, ассоциированный профессор, кафедра эволюционной и экологической биологии, } \\
& \text { Хайфский университет, Израиль, г. Хайфа, e-mail: bolshoy@research.haifa.ac.il }
\end{aligned}
$$

\begin{abstract}
Установлено существование сайтов связывания miRNA не только в 3'-UTR, но и в 5'-UTR и CDS областях mRNA генов животных. Эффективность miRNA-инАуцированной репрессии возрастает с увеличением числа сайтов связывания. Предполагается, что связывание miRNA может быть значительным, если ген содержит повторы последовательностей сайтов в кодирующей области. Было показано, что miR-1322 имеет полисайты в CDS областях mRNA Аесятков человеческих генов. Эксперимента^ьная верификация функциональности большого числа сайтов является трудоемкой. ОАним из способов определения достоверности сайтов Аля miRNA является доказательство существования данных сайтов в mRNA ортологичных генов и анализ их дивергенции в течение эволюции. Проведен анализ консервативности полисайтов miR-1322 в CDS mRNA ATN1, BCL6B, HTT, MAGI1, MLLT3, MN1, THAP11, TВР генов человека и их ортологов. Рассмотренные гены вовлечены в развитие нейродегенеративных и онкологических заболеваний. Результаты исследования показали, что полисайты для связывания miR-1322 обнаруживаются в mRNA ортологичных генов многих видов животных. В процессе эволюции число сайтов связывания изменяется, что указывает на видовую зависимость эффективности регуляции экспрессии Аанных генов, осуществляемой miR-1322. Помимо общего вклаАа в изучение механизмов патогенеза, вызванного участием ATN1, BCL6B, HTT, MAGl1, MLLT3, MN1, THAP11, ТВР генов, проведенный нами анализ позволяет преАложить аАекватную экспериментальную модель животного Аля Аальнейшего изучения регуляции экспрессии описанных генов посредством miR-1322.
\end{abstract}

Ключевые слова: miR-1322, mRNA, ортологичные гены, социально значимые заболевания.

\section{Introduction}

miRNAs are short non-coding RNAs (with 18-25 nucleotides in length) capable of binding to mRNA and repressing protein synthesis (Bartel, 2004: 281297). It is assumed that in animals, interaction of miRNA with the 3'-UTR region of mRNA genes is predominant. To date, most scientific papers are devoted to miRNA interaction with 3'-UTR region of mRNAs. However, in recent years, the existence of sites for miRNA in 5'-UTR and CDS regions of animal mRNAs has been established (Tay, 2008: 1124-1128; Lytle, 2007: 9667-9672; Berillo, 2013:
1016-1024). It is seemed that sites localized in CDS effectively inhibit translation, while sites located in 3'-UTR are more effective in initiating mRNA degradation (Hausser, 2013: 604-615). In a number of studies using Ago-RNA immunoprecipitation and reporter assays, miRNAs have been found to bind to the 5'UTR, CDS and inhibit translation (Tay, 2008: 1124-1128; Lytle, 2007: 9667- 9672; Schnall-Levin, 2010: 15751-6; Hafner, 2010: 129-141). The efficacy of miRNA-mediated repression increases with the number of sites (Schnall-Levin, 2011: 1395-1403).

It is assumed that miRNA binding to mRNA can be significant if the gene contains repeats of site 
sequences in coding region. It was shown that miR1322 has multiple sites in CDS region of mRNAs of dozens of human genes. The presence of multiple binding sites in close proximity significantly increases the probability of interactions between miRNAs and mRNAs, even if mutations occur (Niyazova, 2015: 962637). Moreover, miR-1322 miRNAs has binding sites in $5^{\prime}$ UTRs, CDSs, and $3^{\prime}$ UTRs most of them are located in CDSs. One way to determine the reliability of sites for miRNAs is to prove the existence of these sites in mRNAs of orthologous genes and to analyze their divergence during evolution (Hafner, 2010: 129-141; Gaidatzis, 2007: 69; Atambayeva, 2017: 428). ATN1, BCL6B, HTT, MAGI1, MLLT3, MN1, THAP11, TBP genes are involved in the development of neurodegenerative and oncological diseases (Matilla-Dueñas, 2012: 172-188; Wang, 2014: 192-200; Wang: 2015: 20252-20265; Thion, 2016: 1310-1315; Harjes, 2003: 425-433; Zhang, 2011: 381-385; Bergerson, 2012: 4512-4523; Dejosez, 2008: 1162-1174). To determine possibility of regulation of ATN1, BCL6B, HTT, MAGI1, MLLT3, MN1, THAP11 and $T B P$ genes expression by miR-1322 we studied the arrangement and evolution of miR-1322 binding sites in mRNAs of these genes. Detection of effective miRNA binding sites is a promising direction for diagnosis and therapy of many diseases.

\section{Materials and Methods}

The nucleotide sequences of mRNAs of ATN1, BCL6B, HTT, MAGI1, MLLT3, MN1, THAP11, TBP human genes (Homo sapience - Hsa) and their orthologous genes (Ailuropoda melanoleuca-Ame, Balaenoptera acutorostrata scammoni-Bac, Bos mutus - Bmu, Bos taurus - Bta, Callithrix jacchus - Cja, Camelus ferus - Cfe, Canis familiaris - Cfa, Capra hircus - Chi, Chlorocebus sabaeus - Csa, Cricetulus griseus - Cgr, Equus caballus - Eca, Felis catus - Fca, Gorilla gorilla - Ggo, Heterocephalus glaber-Hgl, Loxodontaa fricana - Laf, Lipotes vexillifer-Lve, Macaca fascicularis - Mfa, Macaca mulatta - Mml, Monodelphis domestica - Mdo, Mus musculus - Mmu, Nannospalax galili - Nga, Nomascus leucogenys - Nle, Oryctolagus cuniculus - Ocu, Ovis aries - Oar, Pan paniscus - Ppa, Pan troglodytes - Ptr, Panthera tigrisaltaica - Pti, Pteropus alecto - Pal, Pongo abelii - Pab, Pantholops hodgsonii - Pho, Rhinopithecus roxellana - Rro, Rattus norvegicus - Rno, Saimiri boliviensis boliviensis - Sbo, Sus scrofa - Ssc, Tupaia chinensis - Tch, Ursus maritimus - Uma) were downloaded from NCBI GenBank (http://www.ncbi.nlm. nih.gov). Nucleotide sequences of human mature miR-1322 (GAUGAUGCUGCUGAUGCUG) were downloaded from the miRBase database (http://mirbase.org).

The miR-1322 binding sites in CDS region of mRNAs of ATN1, BCL6B, HTT, MAGI1, MLLT3, $M N 1, T H A P 11, T B P$ genes were predicted using the MirTarget program. This program defines the features of binding: a) the localization of miRNA binding sites in 5'UTR, CDS and 3'UTR of mRNAs; b) the free energy of hybridization $(\Delta \mathrm{G}, \mathrm{kJ} / \mathrm{mole})$; $\mathrm{c})$ schemes of nucleotide interactions between miRNAs and mRNA. The ratio $\Delta \mathrm{G} / \Delta \mathrm{Gm}(\%)$ was determined for each site ( $\Delta \mathrm{Gm}$ equals the free energy of miRNA binding with its perfect complementary nucleotide sequence). The miRNA binding sites located on the mRNA with a ratio of $\Delta \mathrm{G} / \Delta \mathrm{Gm}$ of $80 \%$ or more were considered. Described binding sites are polysites arranged in series. The program determines position of binding sites beginning from the first nucleotide of 5'UTR mRNA. The MirTarget program also takes into account the hydrogen bonds between adenine (A) and uracil (U), guanine $(\mathrm{G})$ and cytosine $(\mathrm{C}), \mathrm{G}$ and $\mathrm{U}$; $\mathrm{A}$ and $\mathrm{C}$ (Ivashchenko, 2014: e620530)

\section{Results and Discussion}

Using MirTarget program, miR-1322 binding polysites in CDS region of mRNAs of ATN1, BCL6B, HTT, MAGI1, MLLT3, MN1, THAP11, TBP genes were detected. mRNAs and miR-1322 interaction characteristics are shown in the table 1. Free energy of hybridization $(\Delta \mathrm{G})$ of miR-1322 with mRNAs of ATN1, BCL6B, HTT, MAGI1, MLLT3, MN1, THAP11, TBP genes is within $-83 \div$ $-93 \mathrm{~kJ} / \mathrm{mole}$. With the increase in length of polysites, probability of their interaction with miRNAs also increases. $\Delta \mathrm{G} / \Delta \mathrm{Gm}$ of miR-1322 binding polysites ranged from 84 to $93 \%$.

The function of Atrophin-1 protein, encoded by ATN1 gene, is not yet fully understood (http://www. ncbi.nlm.nih.gov). ATN1 gene contains CAG repeats that encode polyglutamine sequence in the protein. In a healthy person, the number of CAG repeats varies from 6 to 35 . The presence of more trinucleotide repeats of CAG is the cause of a rare neurodegenerative disorder - Dentato-rubro-pallido-Lewis atrophy (DRPLA). DRPLA is characterized by cerebral ataxia, myoclonic epilepsy, choreoathetosis and dementia (Matilla-Dueñas, 2012: 172-188). Inhibition of expression of mutant ATN1 protein is considered as a promising strategy for the treatment of DRPLA. In CDS region of mRNA of ATN1 gene 15 sites for 
miR-1322 binding at the position from 1687 to 1751 nucleotides were found. The region of ATN1 gene, which contains miR-1322 binding sites in CDS of mRNA, encodes a polyglutamine sequence that is flanked by conserved oligopeptides in a number of orthologs (Table 2). $\Delta \mathrm{G} / \Delta \mathrm{Gm}$ value of miR-1322 interaction with the mRNA binding sites of ATN1 gene is in the range of 83 to $92 \%$. Most orthologs in mRNA of ATN1 gene have a decrease in the num- ber of miR-1322 binding sites. However, increase in the number of binding sites was found in Ursus maritimus, Equus caballus and Felis catus and is equal to 28, 23 and 17, respectively. Based on the analysis of miR-1322 binding sites number and their physicochemical characteristics, Felis catus (17 miR-1322 binding sites) can be proposed as a model object for studying the regulation of ATN1 gene expression.

Table 1 - Characteristics of miR-1322 polysites in mRNAs of ATN1, BCL6B, HTT, MAGI1, MLLT3, MN1, THAP11, TBP genes

\begin{tabular}{|c|c|c|c|}
\hline $\begin{array}{c}\text { Gene (number of binding } \\
\text { sites) }\end{array}$ & $\begin{array}{c}\text { The position of the beginning } \\
\text { of binding site, } \mathrm{nt}\end{array}$ & $\begin{array}{c}\text { The free energy of } \\
\text { interaction, } \Delta \mathrm{G}, \mathrm{kJ} / \mathrm{mole}\end{array}$ & $\Delta \mathrm{G} / \Delta \mathrm{Gm}, \%$ \\
\hline$H s a-A T N 1(15)$ & $1687 \div 1732$ & $-84 \div-93$ & $83 \div 92$ \\
\hline$H s a-B C L 6 B(6)$ & $764 \div 779$ & $-87 \div-89$ & $85 \div 88$ \\
\hline$H s a-H T T(18)$ & $197 \div 248$ & $-89 \div-91$ & $88 \div 90$ \\
\hline$H s a-M A G I 1(15)$ & $1730 \div 1772$ & $-85 \div-89$ & $81 \div 88$ \\
\hline$H s a-M L L T 3(34)$ & $731 \div 836$ & $-83 \div-89$ & $83 \div 88$ \\
\hline$H s a-M N 1(23)$ & $2519 \div 2591$ & $-85 \div-89$ & $83 \div 92$ \\
\hline$H s a-T H A P 11(27)$ & $548 \div 630$ & $-85 \div-93$ & $-85 \div-89$ \\
\hline$H s a-T B P(29)$ & $451 \div 547$ & \\
\hline
\end{tabular}

Table 2 - Oligopeptides of orthologous ATN1 proteins encoded by miR-1322 binding sites

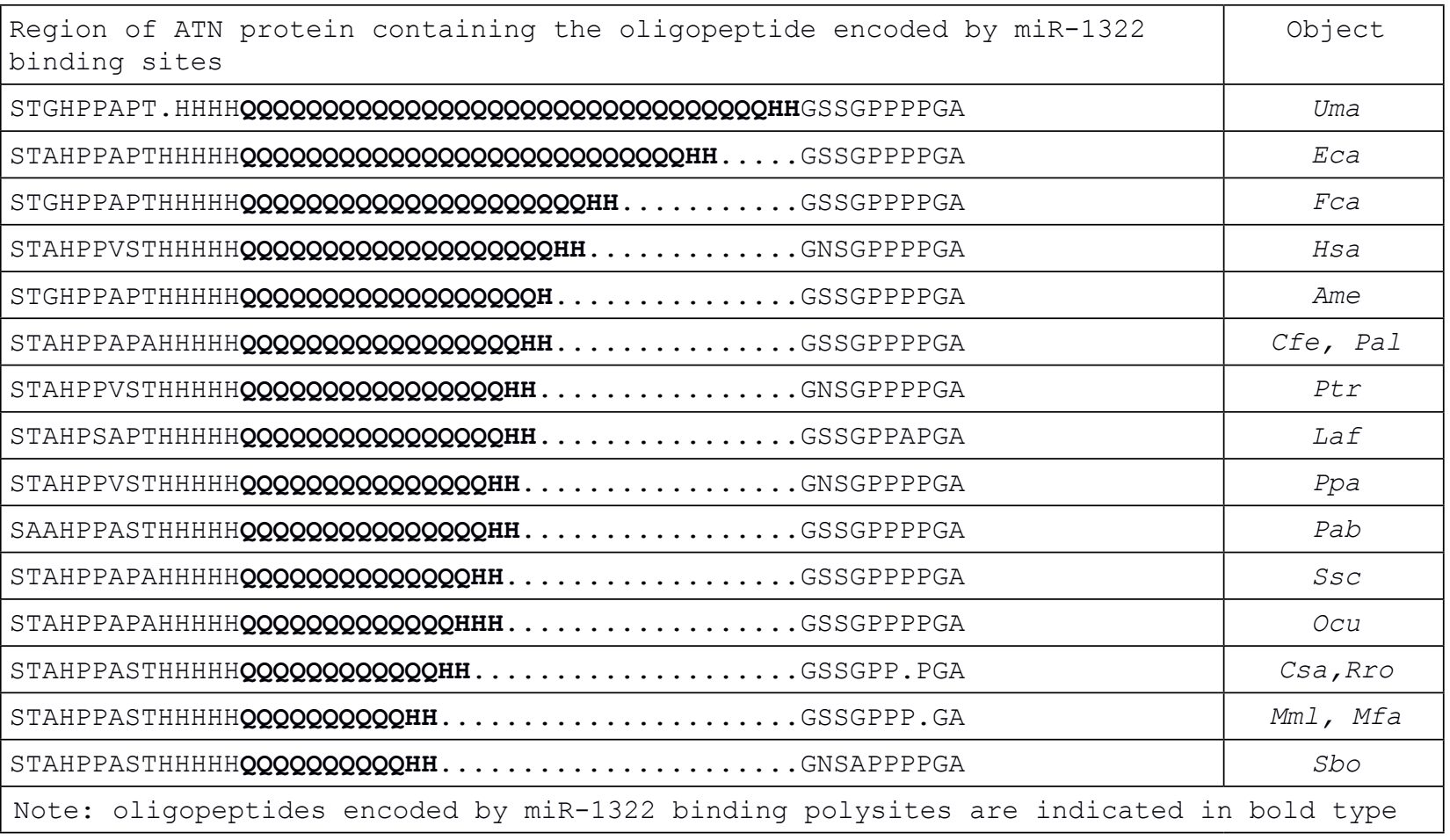


$B C L 6 B$ gene is a homologue of the proto-oncogene of 6 B-cell lymphoma (BCL6). BCL6B inhibits hepatocellular carcinoma metastases in vitro and in mice (Wang, 2014: 192-200). It is suggested that BCL6B suppresses the growth of colon cancer cells, activating the signal system involving P53 (Hu, 2015: 651-662). In CDS mRNA of BCL6B gene, 6 miR-1322 binding sites were iden- tified in the region from 764 to 779 nucleotides of mRNA with an interaction value of $85-88 \%$ of the maximum value of $\Delta \mathrm{G} / \Delta \mathrm{Gm}$ ratio. The region of mRNA of $B C L 6 B$ gene, which contains miR-1322 binding sites in CDS, encodes polyserine. For the group of 23 mammalian species, polyserine in BCL6B protein is flanked by conservative octapeptides (Table 3).

Table 3 - Oligopeptides of orthologous BCL6B proteins encoded by miR-1322 binding sites

\begin{tabular}{|c|c|}
\hline $\begin{array}{l}\text { Region of BCL6B protein containing the oligopeptide encoded by miR-1322 } \\
\text { binding sites }\end{array}$ & object \\
\hline RLPSGDEASSSSSSSSSSSSSSSSSSSSEEGPIPGP & Ptr \\
\hline RLPSGDEASSSSSSSSSSSSSSSSSSSS. EEGPIPGP & Ppa \\
\hline QLPSADEASSSSSSSSSSSSSSGS . . . . EEGPIPGP & $S S C$ \\
\hline RLPSGDEASSSSSSSSSSSS . . . . . . . EEGPIPGP & Hsa, Ggo \\
\hline GLPSGDEASSSSSSSSSGS . . . . . . . EEEGPIPGP & PaI \\
\hline RLPSGDEASSSSSSSSSS .......... EEGPIPGP & Nle \\
\hline RLPSGDEASSSSSSSSS. . . . . . . . . EEGPIPGP & Pab \\
\hline QLPSGDEASSSSSSSSS. . . . . . . . EEGPISSP & Chi \\
\hline RLPSGDEACSSSSSSSS. . . . . . . . . EEGATPGL & Rno \\
\hline RLPSGDEASSSSSSSS . . . . . . . . EEGPILGP & Cja \\
\hline RLPSGDEASSSSSSSS . . . . . . . . EEGPISGP & Bac \\
\hline QLPSGDEASSSSSSSS . . . . . . . . . EEGPISSP & Oar, Pho \\
\hline RLPSGDEASSSSSSS ............EEGPIPGP & Csa, Laf \\
\hline RLPSGDEASSSSSSS ............EEGPISGP & Lve \\
\hline GLPSGDEASSSSSSS .............EEGPIPGP & Eca \\
\hline RLPSGDEACSSSSSS ............EEGTTPGL & $\mathrm{Mmu}$ \\
\hline RLPSGDEASSSSSS . . . . . . . . . EEGPIPGP & $\begin{array}{l}\text { Rro, Mml, } \\
\text { Mfa, Tch }\end{array}$ \\
\hline
\end{tabular}

Most species of $B C L 6 B$ gene orthologs in mRNA contains decrease in the number of miR1322 binding sites. However, BCL6B mRNAs of Pan troglodytes, Pan paniscus and Sus scrofa contain 17, 16 and 9 miR-1322 binding sites, respectively. In mRNA of Rattus norvegicus, there are 4 binding sites for miR-1322 with an interaction energy $\Delta \mathrm{G}$ of $-85 \mathrm{~kJ} / \mathrm{m}$ and $-89 \mathrm{~kJ} / \mathrm{m}$. mRNA of $B C L 6 B$ gene of Mus musculus contains only 1 miR-1322 binding site with an interaction value of $81 \%$ of the maximum value of $\Delta \mathrm{G} / \Delta \mathrm{Gm}$ ratio. When studying the possibility of regulation of $B C L 6 B$ gene expression by miR-1322 molecule in mammals, difference in the number of miR-1322 polysites in mRNA of $B C L 6 B$ gene orthologs should be taken into account, as well as the value of miR-1322 - mRNA interaction.
mRNA of HTT gene also contains miR-1322 binding polysites and encodes a hantingtin HTT protein containing a polyglutamine tract. Wild types of HTT gene of different people have different amounts of CAG repeats (9-35). Huntington's syndrome develops when the number of trinucleotide repeats increases to $36-40$ or more (http:// www.ncbi.nlm.nih.gov). HTT is expressed in all mammalian cells (the highest concentration is in brain and testes). HTT, interacting with proteins involved in processes of endocytosis, apoptosis, morphogenesis and transcription, can also be involved in the regulation of all these processes (Harjes, 2003: 425-433). It is found that mRNA region of HTT gene with CAG repeats (197-248 nucleotides) contains $18 \mathrm{miR}-1322$ binding sites with $\Delta \mathrm{G} / \Delta \mathrm{Gm}$ ratio of 85 to $90 \%$. miR-1322 
binding sites are found in 15 mammalian species mRNAs of HTT gene orthologous (Table 4). mRNA of human HTT gene contains the greatest number of miR-1322 binding sites. A decrease in the number of miR-1322 binding sites in mRNAs of HTT gene orthologs is observed. So, there are 13 miR-1322 binding sites in mRNA of Sus scrofa, 10 miR-1322 binding sites in mRNA of Bos taurus, 8 miR-1322 binding sites in mRNA of Cricetulus griseus, 6 miR-1322 binding sites in mRNA of $P a n$ troglodytes and Pan paniscus, 5 miR-1322 binding sites in mRNA of Chlorocebus sabaeus, Macaca mulatta, Nomascus leucogenys, Canis familiaris and Ovis aries. Decapeptide flanking polyglutamine from the N-terminal in HTT protein is highly conserved. The polyproline amino acid sequence flanking the binding sites from C-terminus of HTT is variable in orthologous proteins. When studying the regulation of HTT gene expression by miR1322 molecule in mammals, the difference in the number of miR-1322 binding polysites in mRNA of HTT gene in orthologs should be considered.

Table 4 - Oligopeptides of orthologous HTT proteins encoded by miR-1322 binding sites

\begin{tabular}{|c|c|}
\hline $\begin{array}{l}\text { Region of HTT protein containing the oligopeptide encoded by miR-1322 } \\
\text { binding sites }\end{array}$ & Object \\
\hline 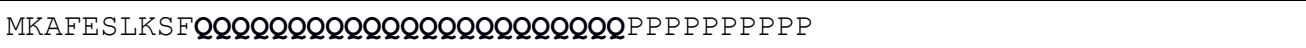 & $\mathrm{Hsa}$ \\
\hline 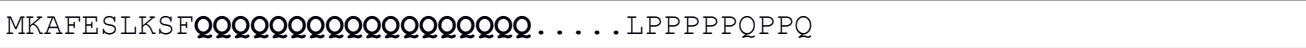 & $S S C$ \\
\hline 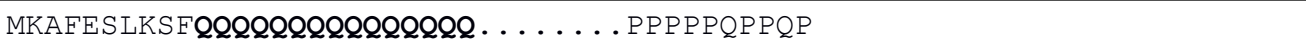 & Bta \\
\hline 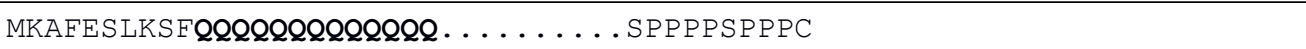 & $\operatorname{Cgr}$ \\
\hline 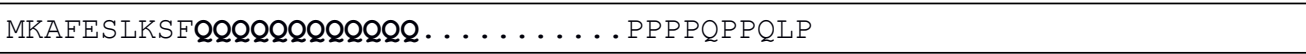 & Laf \\
\hline MKAFESLKSFQQQQQQQQQQQQ . . . . . . . . P PPPPPPLPP & Ptr, Ppa \\
\hline MKAFESLKSFQQQQQQQQQQQ . . . . . . . . . PPPPPPPPPP & Csa \\
\hline MKAFESLKSFQQQQQQQQQQQ . . . . . . . . . PPPPPPPPPPP & $M m 1$ \\
\hline 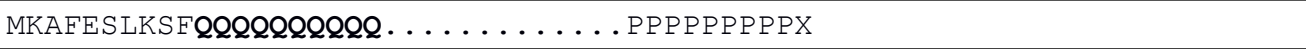 & Nle \\
\hline 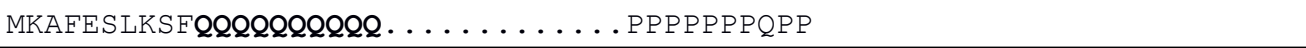 & Cfa \\
\hline 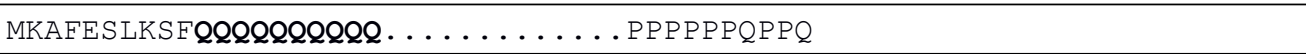 & Oar \\
\hline MKAFESLKSFQQQQQQQQQ . . . . . . . . . PPPQAPPPPP & Rno \\
\hline MKAFESLKSFQQQQQQQQ.............PPPQAPPPPP & Mmu \\
\hline
\end{tabular}

MAGI1 is a family of membrane-bound guanilatkinase (MAGUK), involved in the formation of multiprotein complexes on the inner surface of plasma membrane required for intercellular contacts (http://www.ncbi.nlm.nih.gov). It is shown that MAGI1 can inhibit cellular migration and invasiveness in hepatocellular carcinoma (Zhang, 2011: 381-385). The decrease in MAGI1 expression correlates with an unfavorable prognosis for hepatocellular carcinoma and can serve as a prognostic marker (Zhang, 2012: 93-99). In CDS of mRNA of MAGI1 gene, 15 sites for binding miR-1322 in region from 1730 to 1772 nucleotide of mRNA were detected. The value of MAGII mRNA and miR1322 interaction is $83-88 \%$ of the maximum value of $\Delta \mathrm{G} / \Delta \mathrm{Gm}$. Region of MAGI1, which contains miR-1322 binding sites in CDS of mRNA, encodes polyglutamine sequence. Octapeptides flanking polyglutamine in MAGI1 protein are highly con- served in many mammalian species (Table 5). In the sequence of polyglutamine encoded by binding sites, proline inserts are found. The largest number of miR-1322 binding sites in mRNA of MAGII gene was detected in Pteropus alecto, Pan paniscus and Macaca fascicularis - 22 sites $(\Delta \mathrm{G} / \Delta \mathrm{Gm}$ is equal to $83-88 \%$ ).

MLLT3 is a subunit of transcription elongation complex. MLLT3 is involved in the early regulation of erythroid and megakaryocytic cells (Pina, 2008: 264-273). $\mathrm{t}(9 ; 11)$ translocation in $M L L$ is the cause of acute myeloid leukemia (Bergerson, 2012: 45124523). In CDS region of mRNA of MLLT3, $34 \mathrm{miR}-$ 1322 binding sites were identified at region from 731 to 836 nucleotides with an interaction value of 83.3 to $88 \%$ of the maximum value of $\Delta \mathrm{G} / \Delta \mathrm{Gm}$. Region of MLLT3, which contains miR-1322 binding sites in CDS mRNA, encodes polyserin sequence. Polyserin in orthologues MLLT3 proteins is flanked by 
conservative amino acids (Table 6). There are identical number of miR-1322 binding sites and flanking regions in mRNA of MLLT3 of Mus musculus and Homo sapiens. Therefore to study the regulation of MLLT3 gene expression by miR-1322 molecule, the choice of Mus musculus as an animal model object will be adequat. An increase in the number of binding sites was found in Macaca mulatta, Macaca fascicularis, Chlorocebus sabaeus, Pan troglodytes (36); Pan paniscus, Gorilla gorilla gorilla (35). The maximum number of binding sites was found in Nannospalax galili -46 .

Table 5 - Oligopeptides of orthologous MAGI1 proteins encoded by miR-1322 binding sites

\begin{tabular}{|c|c|}
\hline $\begin{array}{l}\text { Region of MAGIl protein containing the oligopeptide encoded by } \\
\text { miR-1322 binding sites }\end{array}$ & object \\
\hline AKRKKQ IEQQQQQQQQQPQQQPQQQQQQQQQQQQQQQQQPQQQ.EEWTEDH & Pal \\
\hline AKRKKQLEQQQQQQQQQQQQQQQQQQQQQQQQQQQQ . . . . . . TEEWTEDH & Ppa, Mfa \\
\hline AKRKKQLEQQQQQQQQQQQQQQQQQQQQQQQQQQ . . . . . . . TEEWTEDH & Csa \\
\hline AKRKKQLEQQQQQQPQQPQQLQQQQQQQQPPP . . . . . . . . PEEWTEDH & Nga \\
\hline AKRKKQLEQQQQQQQQQQQQQQQQQPQQ............TEEWTEDH & Sbo, Cja \\
\hline AKRKKQLEQQQQQQQQQQQQQQQQQQQQ . . . . . . . . . TEEWTEDH & Hsa \\
\hline AKRKKQLEQQQQQQQPQPQPQQQQQQPQ . . . . . . . . EEWTEDH & TCh \\
\hline 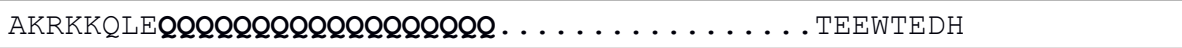 & Ggo \\
\hline AKRKKQLEQQQQQQQQQQQQPPPQQQQ . . . . . . . . . . . SEEWAEDH & Mdo \\
\hline AKRKKQLEQQQQPQQQQQQQQQQQQP . . . . . . . . . . . PEEWTEDH & Cfa \\
\hline AKRKKQLEQQQQPQQPQQQQQQQQR ..............PEEWTEDH & Uma \\
\hline AKRKKQLEQQQQQQQQQQQQQQQPPP . . . . . . . . . . . AEEWTEDH & $\mathrm{Ocu}$ \\
\hline 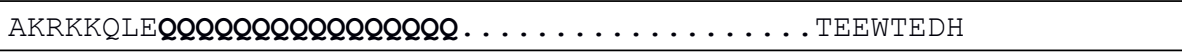 & Ptr \\
\hline AKRKKQLEQPQQPQQQQPQQQQQQ ..............PEEWTEDH & Ame \\
\hline 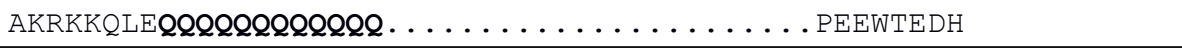 & Bmu, Pho, Chi, Oar \\
\hline AKRKKQ IEQQQQQQQQQQQQQQ . . . . . . . . . . . . . . . PEEWTEDH & Eca \\
\hline 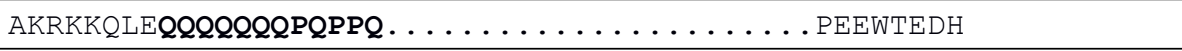 & Mmu \\
\hline AKRKKQLEQQ & Bta \\
\hline AKRKKQLEQQQPRQQQQ . . . . . . . . . . . . . . . PEEWTEDH & Bac \\
\hline 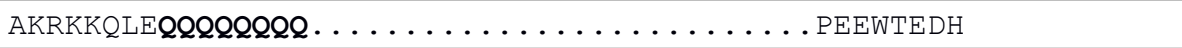 & $C f e$ \\
\hline
\end{tabular}

Table 6 - Oligopeptides of orthologous MLLT3 proteins encoded by miR-1322 binding sites

\begin{tabular}{|c|c|}
\hline $\begin{array}{l}\text { Region of MLLT3 protein containing the oligopeptide encoded by } \\
\text { miR-1322 binding sites }\end{array}$ & object \\
\hline DPNRSIHTZZSSSSSSSSSSSSSSSSSSSSSSSSSSSSSSSSSSSSSSSSTSFSKPHK & Nga \\
\hline DPNRSIHTZSSSSSSSSSSSSSSSSSSSSSSSSSSSSSSSSSSSSS . . . TSFSKPHK & Mml, Mfa, Ptr, Csa \\
\hline DPNRSIHTZSSSSSSSSSSSSSSSSSSSSSSSSSSSSSSSSSSSS . . . TSFSKPHK & Ppa, Ggo \\
\hline DPNRSIHTZSSCSSSSSSSSSSSSSSSSSSSSSSSSSSSSSSSSS . . . TSFSKPHK & Chi \\
\hline DPNRSIHTZSSSSSSSSSSSSSSSSSSSSSSSSSSSSSSSSSSS . . . . TSFSKPHK & Nle, Cja \\
\hline 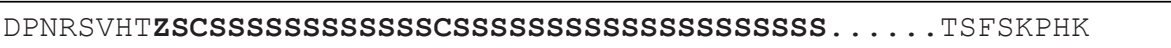 & Mda, Bta \\
\hline DPNRSIHTZSSSSSSSSSSSSSSSSSSSSSSSSSSSSSSSSSSS . . . . TSFSKPHK & Hsa, Mmu \\
\hline DPNRSVHTZSCSSSSSSSSSSSSSSSSSSSSSSSSSSSSSSSSS . . . . TSFSKPHK & Eca \\
\hline DPNRSIHTZCSSSSSSSSSSSSSSCSSSSSSSSSSSSSSSSSS . ..... TSFSKPHK & Cfa, FCa \\
\hline DPNRSVHTZCSSSSSSSSSSSSSSSSSSSSSSSSSSSSSSSSS . . . . . TSFSKPHK & Laf \\
\hline
\end{tabular}


continuation of table 6

\begin{tabular}{|c|c|}
\hline $\begin{array}{l}\text { Region of MLLT3 protein containing the oligopeptide encoded by } \\
\text { miR-1322 binding sites }\end{array}$ & Object \\
\hline DPNRS IHTZSCSSSSSSSSSSSSSSSSSSSSSSSSSSSSSSS . . . . . TSFSKPHK & $S S C$ \\
\hline DPNRSVHTZSSSSSSSSSSSSSSSSSSSSSSS .............TSFSKPHK & Pal \\
\hline DPNRS IHTZSSSSSSSSSSSSSSSSSSSSS .............. TSFSKPHK & Rro \\
\hline DPNRS IHTZSCSSSSSSSSSSSSSSSSS .............. TSESKPHK & Pho \\
\hline 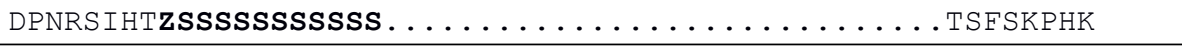 & Cfe \\
\hline DPNRS IHTZSSSSSSSSSS . . . . . . . . . . . . . . . TSFSKPHK & Oar \\
\hline 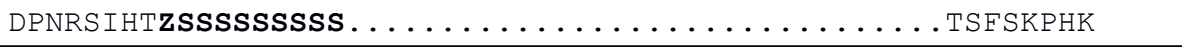 & Sbo \\
\hline \multicolumn{2}{|c|}{$\begin{array}{l}\text { Note: oligopeptides encoded by miR-1322 binding polysites are indicated in bold type; } \\
\mathrm{z}=7 \mathrm{~S}\end{array}$} \\
\hline
\end{tabular}

The product of meningioma 1 gene $(M N 1)$ is a transcriptional coactivator, participates in the development of meningiomas (http://www. ncbi.nlm.nih.gov). Increased MN1 expression is observed in some types of acute myeloid leukemia (Grosveld, 2007: 336-339). Overexpression of MN1 accelerates the development of aggressive leukemia by suppressing $\mathrm{p} 53$, which leads to a decrease in apoptosis and resistance to chemotherapy (Pardee, 2012: e4318). In CDS region of mRNA gene of MN1 gene, 23 binding sites for miR-1322 with interaction energy of $83-87.5 \%$, located from 2519 to 2610 nucleotides were found. The region with polysites encodes polyglutamine sequence (Table 7).

Table 7 - Oligopeptides of orthologous MN1 proteins encoded by miR-1322 binding sites

\begin{tabular}{|c|c|}
\hline $\begin{array}{l}\text { Region of MN1 protein containing the oligopeptide encoded by miR-1322 } \\
\text { binding sites }\end{array}$ & Object \\
\hline 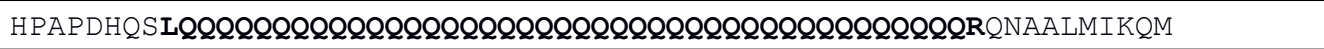 & $\mathrm{HgI}$ \\
\hline 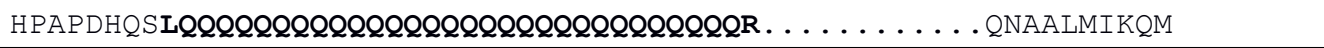 & $P a b$ \\
\hline 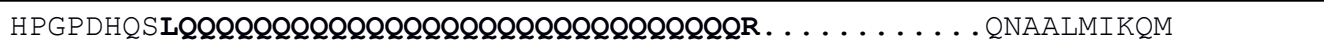 & Rno \\
\hline 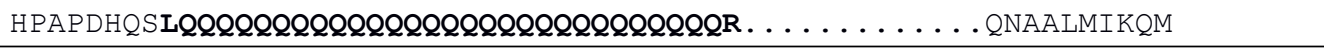 & Ptr \\
\hline 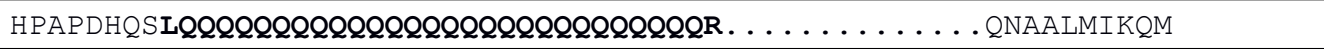 & Hsa, Ggo \\
\hline 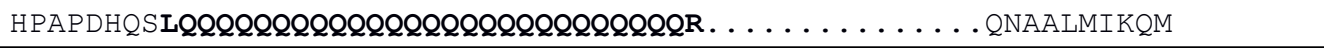 & Nle \\
\hline 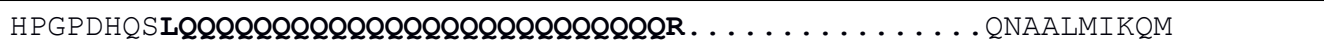 & Mmu \\
\hline 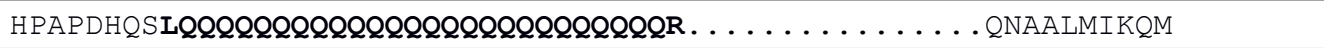 & Csa \\
\hline 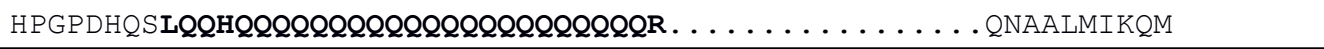 & $\mathrm{Nga}$ \\
\hline 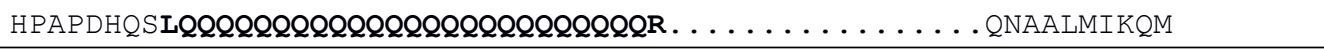 & Mml, Mfa, Rro \\
\hline 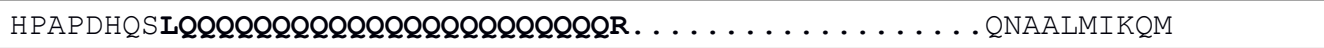 & $B a C$ \\
\hline HPAPDHQSLQQQQHQQQQQQQQQQQQQR . . . . . . & $S S C$ \\
\hline 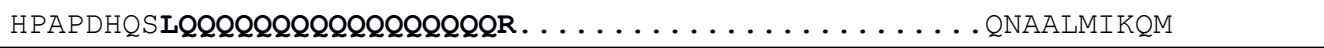 & FCa \\
\hline 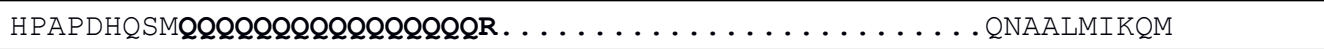 & $\mathrm{OCu}$ \\
\hline 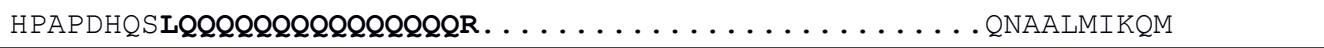 & Lve, Eca \\
\hline 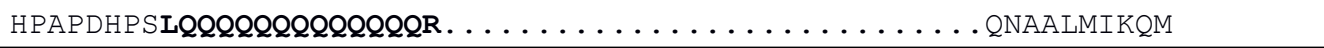 & Chi, Bta \\
\hline 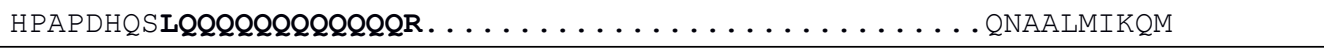 & $\mathrm{PaI}$ \\
\hline 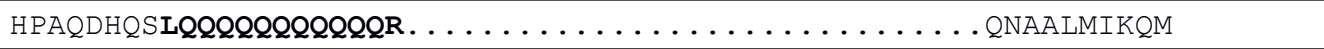 & Laf \\
\hline Note: oligopeptides encoded by miR-1322 binding polysites are indic & in bold type \\
\hline
\end{tabular}


Octapeptides flanking oligopeptides encoded by miR-1322 binding sites in MN1 protein are highly conserved. The number of binding sites for miR-1322 varies among mammalian species. Thus, increase in the number of binding sites occurs in Pan troglodytes -24, in Rattus norvegicus and Pongo abelii- 25 and Heterocephalus glaber - 37. In Gorilla gorilla gorilla, the number of binding sites and sequences of polyglutamine-flanking amino acids are identical to those in human MN1. As a model object, in the study of regulation of $M N 1$ gene expression by miR-1322, Gorilla gorilla gorilla (23 binding sites) and Rattus norvegicus (25 binding sites) can be chosen. However, the difference in the number of binding sites can influence degree of suppression of MN1 protein translation, which should be taken into account when interpreting experimentally obtained results.

Another target gene of miR-1322 is THAPl1 (THAP domain containing 11), a gene that contains THAP domain. THAP family proteins act as transcription factors that control cell proliferation, apoptosis and epigenetic silencing (http://www. ncbi.nlm.nih.gov). It has been shown that THAP11 is involved in the regulation of cell proliferation, embryogenesis, and pluripotency of embryonic stem cells (Dejosez, 2008: 1162-1174). Knockdown of THAP11 in colon cancer SW620 cell line led to a significant decrease in proliferation (Parker, 2012: 1654-1670). Overexpression of THAP11 changes the expression levels of such transcription factors as c-Myc, c-Myb, GATA-2 and Fli1 (Kong, 2014: e91557). In CDS region of mRNA of THAP 11 gene, 27 miR-1322 binding sites were detected in mRNA region from 548 to 630 nucleotides. THAP11 gene region, which contains the miR-1322 binding sites in CDS mRNA, encodes polyglutamine. The value of miR-1322 - mRNA of THAP11 interaction is 83 $-92 \%$ of the maximum value of ratio $\Delta \mathrm{G} / \Delta \mathrm{Gm}$. Octapeptides flanking polyglutamine in the THAP11 protein of orthologs are highly conserved (Table 8).

Table 8 - Oligopeptides of orthologous THAP11 proteins encoded by miR-1322 binding sites

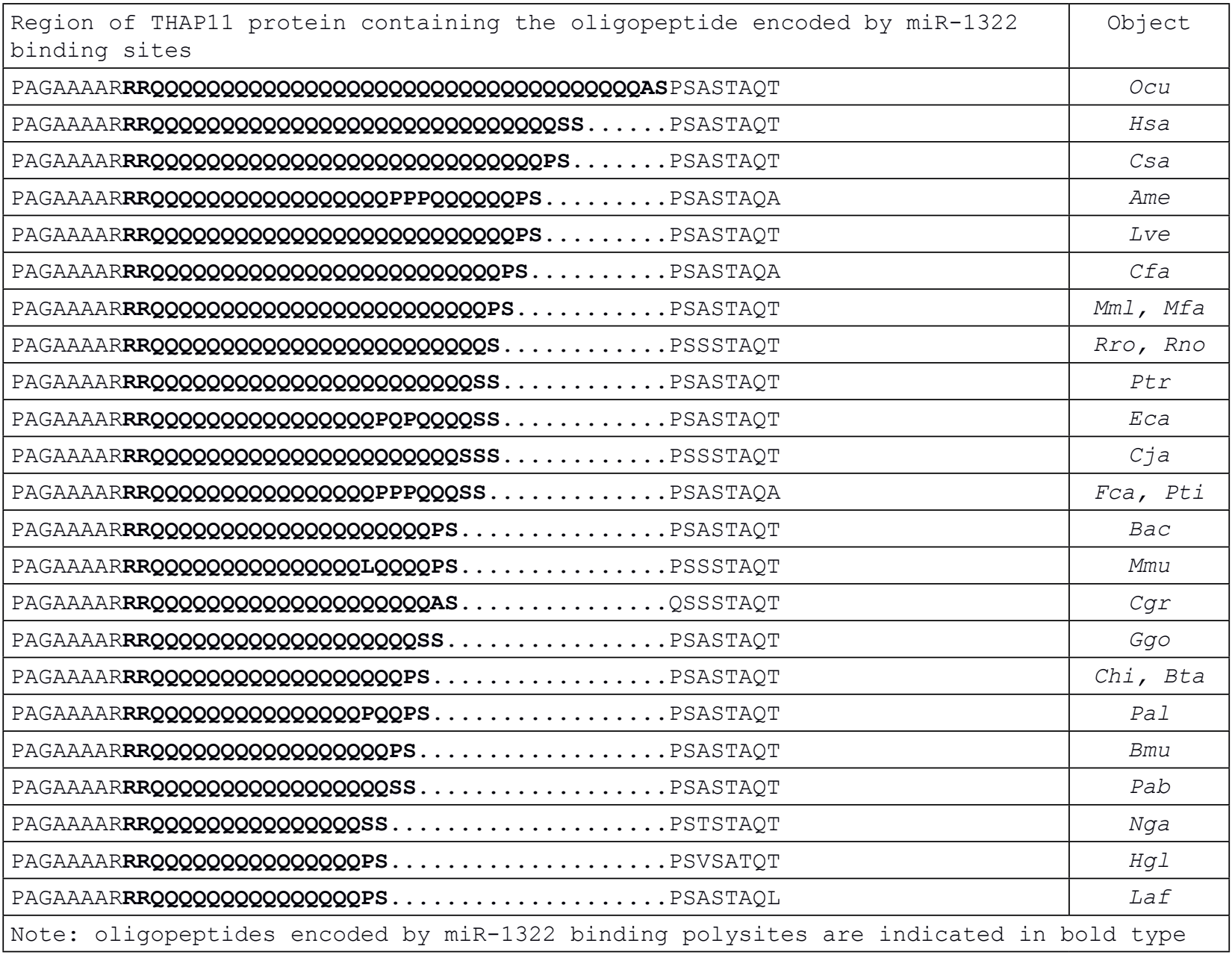


Most species of orthologs in mRNA of THAP11 gene have a decrease in the number of miR-1322 binding sites. So, 26 miR-1322 binding sites in mRNA of Chlorocebus sabaeus, 24 in mRNA of Lipotes vexillifer, 23 in mRNA of Canis familiaris, 22 in mRNA of Macaca mulatta and Macaca fascicularis, 21 in mRNA of Pan troglodytes and Pan paniscus, 18 in mRNA of Mus musculus. The maximum number of binding sites was found in Oryctolagus cuniculus - 33, which makes it possible to choose it as an animal model for study of pathologies caused by THAP11-miR-1322 association.

TBP is a TATA-binding protein and a group of evolutionarily conserved proteins TBP-associated factors or TAFs are part of the TFIID transcription factor. TBP is required for transcription of RNA polymerase II. The TBP contains a sequence of 25-
42 glutamine residues. The expansion of the number of repeats of glutamine to 45-66 is associated with development of a neurodegenerative disease - spinal carbellar ataxia 17 (http://www.ncbi.nlm. nih.gov). In CDS region of mRNA of TBP gene, 29 sites for miR-1322 binding are identified in region from 451 to 547 mRNA nucleotides. Part of mRNA of TBP gene containing miR-1322 binding sites encodes polyglutamine (Table 9). The interaction value of miR-1322 and mRNA of TBP gene is $83-$ $87 \%$ of the maximum values of $\Delta \mathrm{G} / \Delta \mathrm{Gm}$. Decapeptides flanking polyglutamine in TBP protein from $\mathrm{N}$-terminal side are highly conserved. In mRNAs of orthologues $T B P$ genes, a decrease in the number of miR-1322 binding sites is observed. So, 26 miR1322 binding sites in mRNA of Pan troglodytes, 23 - in mRNA of Rhinopithecus roxellana.

Table 9 - Oligopeptides of orthologous TBP proteins encoded by miR-1322 binding sites

\begin{tabular}{|c|c|}
\hline $\begin{array}{l}\text { Region of ThP protein containing the oligopeptide encoded by miR-1322 } \\
\text { blnang Sites }\end{array}$ & object \\
\hline 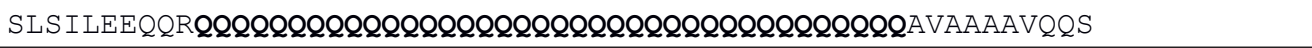 & Hsa \\
\hline SLS ILEEQQRQQQQQQQQQQQQQQQQQQQQQQQQQQQQQQQQQQQ . . A AVAAAAVQQS & Ptr \\
\hline SLS I LEEQ QRQQQQQQQQQQQQQQQQQQQQQQQQQQQQQQQQ . . . . . AVAATAVQQS & Rro \\
\hline SLS I LEEQ QRQQQQQQQQQQQQQQQQQQQQQQQQQQQQQQQ . . . . . . AVAAAAVQQS & Ppa \\
\hline SLS ILEEQQRQQQQQQQQQQQQQQQQQQQQQQQQQQQQQQ . . . . . . . AVAAAAVQQS & Ggo \\
\hline 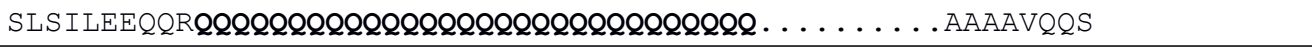 & Eca \\
\hline SLS I LEEQ QRQQQQQQQQQQQQQQQQQQQQQQQQQQQQQ. . . . . . . AAVAAA. QQS & Lve \\
\hline SLS ILEEQ QRQQQQQQQQQ & Nle, Cja \\
\hline 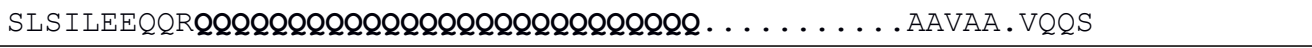 & Chi \\
\hline 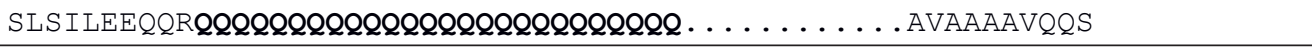 & $P a b$ \\
\hline SLS I LEEQQRQQQQQQQQQQQQQQQQQQQQQQQQQQQ . . . . . . . . . AVAAAAVQQS & $M m I, M f a$ \\
\hline 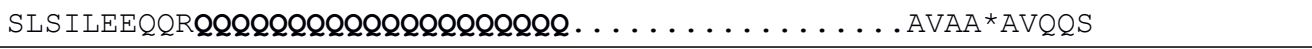 & $\mathrm{Ocu}$ \\
\hline SLSILEEQQRQQQQQQQQQ & $\underline{\text { Rno }}$ \\
\hline 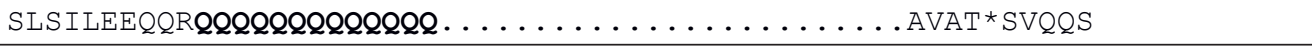 & $\underline{M m u}$ \\
\hline
\end{tabular}

We assume that miRNA targeting can be significant if the gene contains repeats of binding site sequences. We have shown that miR-1322 has polysites in CDS regions of mRNA of dozens of human genes. Experimental verification of functionality of such a large number of sites is laborious. One way to determine the reliability of sites for miRNA is to prove the existence of these sites in mRNA of orthologous genes and to analyze their divergence during evolution. We analyzed the conservation of miR-1322 polysites in CDS mRNAs of ATN1, BCL6B, HTT, MAGI1, MLLT3, MN1,
THAP11, TBP human genes and their orthologues. The results of the study of the conservation of miR1322 polysites in CDSs of ATN1, BCL6B, HTT, MAGI1, MLLT3, MN1, THAP11, TBP human genes and their orthologues showed that nucleotide sequences of miRNA binding sites in mRNA can be translated in different reading frames with the synthesis of polyQ or polyS. Oligopeptides flanking polyglutamine or polyserin encoded by miR1322 binding sites are highly conserved. During evolution, the number of miR-1322 binding sites changes, which indicates species dependence of the 
efficiency of regulation of these genes expression by miR-1322.

An increase in the number of binding sites for miR-1322 in mRNAs of ATN1 and HTT genes can lead to development of neurodegenerative diseases. Normally, the CAG segment is repeated up to 35 times within these gene, mutant ATN1 gene contains from 48 to 93 CAG repeats, mutant HTT gene contains to 39-75 copies of a trinucleotide repeat (MatillaDueñas, 2012: 172-188; Bobori, 2015: 59-65). It can be assumed that trinucleotide repeats in mRNAs can participate in the development of diseases as targets for miR-1322. The energy of interaction between miR-1322 and mRNAs of ATN1, BCL6B, HTT, MAGI1, MLLT3, MN1, THAP11, TBP genes is between $-84 \mathrm{~kJ} / \mathrm{mole}$ and $-93 \mathrm{~kJ} /$ mole. However, when predicting the probability of inhibition degree of gene expression by miRNAs, it is not enough to know only their affinity to mRNAs. Effect of suppression of genes expression directly depends on the ratio of mRNAs and miRNAs molecules concentrations, which must be taken into account when planning experiments and processing data. This can be explained by the scheme:

$$
\begin{gathered}
\operatorname{miRNA}+\operatorname{RISC} \leftrightarrow \operatorname{RISC}(\sim \operatorname{miRNA}) \\
\leftrightarrow \operatorname{RISC}(\sim \operatorname{miRNA})+\text { mRNA } \leftrightarrow \\
\operatorname{RISC}(\sim \text { miRNA }) \approx \text { mRNA } \rightarrow \\
\operatorname{RISC}(\sim \text { miRNA })+\text { res-mRNA }
\end{gathered}
$$

where RISC (RNA-induced silencing complex) - association of proteins contained in RISC complex without miRNA; RISC( miRNA) - association of proteins contained in RISC complex without miRNA with miRNA; RISC $(\sim$ miRNA $) \approx$ mRNA RISC complex with miRNA and mRNA, formed by hydrogen bonds; res-mRNA - restricted mRNA.

The scheme shows following processes: miRNA binds to a group of RISC proteins, forming RISC ( $\sim$ miRNA). Further, RISC $(\sim$ miRNA) binds to mRNA via hydrogen bonds $(\approx)$ and inhibits protein synthesis, or RISC cleaves mRNA, which is further degradated by cytoplasmic restriction enzymes. The stage of binding RISC( miRNA) to mRNA is reversible and in the absence of their interaction, mRNA can be used for translation. It follows from this scheme that different effects can be observed depending on the ratio of concentrations of miRNAs and mRNAs. Assume that miRNA is completely complementary to binding site in mRNA, that is, it has a high affinity to mRNA. Despite this, at low concentrations of miRNAs compared to mRNAs, the complex will have little effect on inhibition of translation, since miRNAs will bind with a small part of synthesized mRNAs. If concentration of
miRNAs is comparable or greater than concentration of mRNAs, protein synthesis will be slowed down or completely inhibited. For example, with an average affinity of miRNA-mRNA interaction, the effect of complete inhibition of protein synthesis can be achieved at miRNA concentrations much greater than mRNAs.

\section{Conclusion}

In the mRNAs of orthologous genes of studied animal species, miR-1322 binding sites are identified that encode polyamino acids of glutamine and serine. The number of polyamino acids varies during the evolution of species and there is a tendency to increase the length of polyamino acids in proteins during evolution. Revealed changes in the number of miR-1322 polysites can influence the susceptibility of various species to diseases caused by involvement of described genes. Our analysis allows us to supplement existing knowledge about the role of miR-1322 in key biological processes and to make general contribution to study of diseases associated with ATN1, BCL6B, HTT, MAGI1, MLLT3, MN1, THAP 11, TBP genes. Moreover, it is possible to propose an adequate experimental animal model for further study of regulation of described genes expression by miR-1322. Based on the analysis of the number of miR-1322-3p binding sites and their physicochemical properties as a model object for studying the regulation of the expression of the described genes, the following can be proposed: for ATN1-Felis catus (17 binding sites); for BCL6BGorilla gorilla (6 binding sites); for HTT - Sus scrofa (13 binding sites), for MAGI1 - Saimiri boliviensis and Callithrix jacchus (15 binding sites); for MLLT3 - Mus musculus (34 binding sites), MN1 - Gorilla gorilla gorilla (23 binding sites) and Rattus norvegicus (25 binding sites), for THAP11 - Chlorocebus sabaeus (26 binding sites) and Oryctolagus cuniculus (33 binding sites), for TBP Pan troglodytes (26 binding sites).

Assosiation of miR-1322 with its target genes can serve as markers for some neurodegenerative disorders and types of cancer. For adequate choice of experimental animals, it is necessary to take into account the number of binding sites and interaction characteristics between miRNAs and mRNAs of target genes.

The study was carried out with financial support of the Ministry of Education and Science of the Republic of Kazakhstan within the framework of grant. We are grateful to Pyrkova A.Yu. for conducting calculations on MirTarget program. 


\section{References}

1 Atambayeva S, Niyazova R, Ivashchenko A, Pyrkova A, Pinsky I, Akimniyazova A, Labeit S. (2017) The Binding sites of miR-619-5p in the mRNAs of human and orthologous genes, BMC Genomics, vol. 18, no. 428. DOI:10.1186/s12864-017-3811-6.

2 Bartel DP. (2004) MicroRNAs: genomics, biogenesis, mechanism, and function, Cell, vol. 116, no. 2, pp. 281-297. DOI: 10.1016/S0092-8674(04)00045-5.

3 Berillo OA, Issabekova AS, Régnier M, Ivashchenko AT. (2013) Characteristics of binding sites of intergenic, intronic and exonic miRNAs with mRNAs of oncogenes coding intronic miRNAs, African Journal of Biotechnology, vol. 12, no. 11, pp. 1016-1024

4 Bergerson RJ, Collier LS, Sarver AL, Been RA, Lugthart S, Diers, MD et al. (2012). An insertional mutagenesis screen identifies genes that cooperate with Mll-AF9 in a murine leukemogenesis model, Blood, vol. 119, no. 19, pp. 4512-4523. DOI:10.1182/ blood-2010-04-281428

5 Bobori C. (2014) Molecular Genetics of Huntington's Disease, Adv Exp Med Biol, vol. 822, pp. 59-65. DOI: 10.1007/9783-319-08927-0_9

6 Dejosez M, Krumenacker JS., Zitur LJ, Passeri M, Chu LF, Songyang, Z et.al. (2008). Ronin is essential for embryogenesis and the pluripotency of mouse ES cells, Cell, vol. 133, no. 7, pp. 1162-1174. DOI: 10.1016/j.cell.2008.05.047.

7 Gaidatzis D, van Nimwegen E, Hausser J, Zavolan M. (2007) Inference of miRNA targets using evolutionary conservation and pathway analysis, BMC Bioinformatics, no. 8, p. 69. DOI:10.1186/1471-2105-8-69

8 Grosveld GC. (2007) MN1, a novel player in human AML, Blood Cells Mol Dis, vol. 39, no. 3, pp. 336-9. DOI:10.1016/j. bcmd.2007.06.009.

9 Hafner M, Landthaler M, Burger L, Khorshid M, Hausser J, Berninger P, Rothballer A, Ascano M Jr, Jungkamp AC, Munschauer M, Ulrich A, Wardle GS, Dewell S, Zavolan M, Tuschl T (2010) Transcriptome-wide identification of RNA-binding protein and microRNA target sites by PAR-CLIP, Cell, vol. 141, no. 1, pp. 129-41. DOI:10.1016/j.cell.2010.03.009

10 Harjes P, Wanker EE. (2003) The hunt for huntingtin function: interaction partners tell many different stories, Trends in Biochem Sci, vol. 28, no. 8, pp. 425 - 433. DOI: 10.1016/S0968-0004(03)00168-3

11 Hausser J, Syed AP, Bilen B, Zavolan M. (2013) Analysis of CDS-located miRNA target sites suggests that they can effectively inhibit translation, Genome Res, vol. 23, no. 4, pp.604-615. DOI: 10.1101/gr.139758.112.

$12 \mathrm{http}: / /$ www.ncbi.nlm.nih.gov

$13 \mathrm{http}: / /$ mirbase.org

$14 \mathrm{Hu} \mathrm{S}$, Cao B, Zhang M, et al. (2015) Epigenetic silencing BCL6B induced colorectal cancer proliferation and metastasis by inhibiting P53 signaling. Am J Cancer Res, vol. 5, no. 2, pp. 651-662.

15 Ivashchenko A, Berillo O, Pyrkova A, Niyazova R. (2014) Binding Sites of miR-1273 Family on the mRNA of Target Genes. BioMed Res Int, vol. 2014, p. 620530. DOI: 10.1155/2014/620530.

16 Kong XZ, Yin RH, Ning HM, Zheng WW, Dong XM, Yang Y, Xu FF, Li JJ, Zhan YQ, Yu M, Ge CH, Zhang JH, Chen H, Li CY, Yang XM. (2014) Effects of THAP11 on erythroid differentiation and megakaryocytic differentiation of K562 cells, PLoS One, vol. 9, no. 3, e91557. DOI:10.1371/journal.pone.0091557

17 Lytle JR., Yario T.A., Steitz JA. (2007) Target mRNAs are repressed as efficiently by microRNA-binding sites in the $5^{\prime}$ UTR as in the 3' UTR, Proc. Natl. Acad. Sci USA, vol. 104, no. 23, pp. .9667-9672. DOI:10.1073/pnas.0703820104.

18 Matilla-Dueñas A. (2012) Machado-Joseph Disease and other Rare Spinocerebellar Ataxias. In: Ahmad S.I. (eds) Neurodegenerative Diseases, Advances in Experimental Medicine and Biology, vol. 724, pp. 172-188. DOI: 10.1007/978-1-4614-0653-2_14

19 Niyazova R., Berillo O, Atambayeva S, Pyrkova A, Alybayeva A, Ivashchenko A. (2015). miR-1322 binding sites in paralogous and orthologous genes, BioMed Res Int, vol.2015, no. 962637. DOI: 10.1155/2015/962637

20 Pardee TS. (2012) Overexpression of MN1 confers resistance to chemotherapy, accelerates leukemia onset, and suppresses p53 and Bim induction, PLoS One, vol.7, no.8, e43185. DOI:10.1371/journal.pone.0043185

21 Parker JB, Palchaudhuri S, Yin H, Wei J, Chakravarti D. (2012) A transcriptional regulatory role of the THAP11-HCF-1 complex in colon cancer cell function, Mol Cell Biol, vol. 32, no. 9, pp. 1654-70. DOI: 10.1128/MCB.06033-11.

22 Pina C, May G, Soneji S, Hong D, Enver T. (2008) MLLT3 regulates early human erythroid and megakaryocytic cell fate, Cell Stem Cell, vol. 2, no. 3, pp. 264-73. DOI: 10.1016/j.stem.2008.01.013.

23 Schnall-Levin M, Zhao Y, Perrimon N, Berger B. (2010) Conserved microRNA targeting in Drosophila is as widespread in coding regions as in 3UTRs, Proc Natl Acad Sci USA, vol. 107, no. 36, pp. 15751-6. DOI:10.1073/pnas.1006172107

24 Schnall-Levin M, Rissland OS, Johnston KW (2011) Unusually effective miRNA targeting within repeat-rich coding regions of mammalian mRNAs, Genome Res, vol. 21, no. 9, pp. 1395-1403. DOI: 10.1101/gr.121210.111

25 Thion MS, Tézenas du Montcel S, Golmard J-L, et al. (2016) CAG repeat size in Huntingtin alleles is associated with cancer prognosis, European Journal of Human Genetics, vol. 24, no .9, pp. 1310-1315. DOI:10.1038/ejhg.2016.13

26 Tay Y, Zhang J, Thomson AM, Lim B, Rigoutsos I. (2008) MicroRNAs to Nanog, Oct4 and Sox2 coding regions modulate embryonic stem cell differentiation, Nature, vol. 455 pp.1124-1128. DOI:10.1038/nature07299

27 Wang J, Dong L, Xu L, Chu ES, Chen Y, Shen J, et al. (2014) B cell CLL/lymphoma 6 member B inhibits hepatocellular carcinoma metastases in vitro and in mice, Cancer Lett, vol. 355, no. 2, pp. 192-200. DOI:10.1016/j.canlet.2014.08.025. 
Yurikova O. et al.

28 Wang W, Huang P, Wu P, et al. (2015) BCL6B expression in hepatocellular carcinoma and its efficacy in the inhibition of liver damage and fibrogenesis, Oncotarget, vol. 6, no. 24, pp. 20252-20265. DOI: 10.18632/oncotarget.3857

29 Zhang G, Wang Z. (2011) MAGI1 inhibits cancer cell migration and invasion of hepatocellular carcinoma via regulating PTEN, Zhong Nan Da Xue Xue Bao Yi Xue Ban, vol. 36, no. 5, pp. 381-385 DOI:10.3969/j.issn.1672-7347.2011.05.002

30 Zhang G, Liu T, Wang Z. (2012) Downregulation of MAGI1 associates with poor prognosis of hepatocellular carcinoma. J Invest Surg, vol. 25, no. 2, pp. 93-99. DOI: 10.3109/08941939.2011.606875.

\section{References}

1 Bartel DP. MicroRNAs: genomics, biogenesis, mechanism, and function // Cell. - 2004. -Vol. 116, No. 2. - P. 281-297. DOI: 10.1016/S0092-8674(04)00045-5.

2 Tay Y, Zhang J, Thomson AM, Lim B, Rigoutsos I. MicroRNAs to Nanog, Oct4 and Sox2 coding regions modulate embryonic stem cell differentiation // Nature. - 2008. - Vol. 455. - P.1124-1128. DOI:10.1038/nature07299

3 Lytle JR., Yario T.A., Steitz JA. Target mRNAs are repressed as efficiently by microRNA-binding sites in the 5' UTR as in the 3' UTR // Proc. Natl. Acad. Sci USA. - 2007. - Vol. 104, No. 23. - P. 9667-9672. DOI:10.1073/pnas.0703820104.

4 Berillo OA, Issabekova AS, Régnier M, Ivashchenko AT. Characteristics of binding sites of intergenic, intronic and exonic miRNAs with mRNAs of oncogenes coding intronic miRNAs // African Journal of Biotechnology. -2013. - Vol.12, No. 11. -P. 10161024

5 Hausser J, Syed AP, Bilen B, Zavolan M. Analysis of CDS-located miRNA target sites suggests that they can effectively inhibit translation // Genome Res. - 2013. - Vol. 23, No. 4. - P. 604-615. DOI: 10.1101/gr.139758.112.

6 Schnall-Levin M, Zhao Y, Perrimon N, Berger B. Conserved microRNA targeting in Drosophila is as widespread in coding regions as in 3UTRs // Proc Natl Acad Sci USA. - 2010. - Vol. 107, No. 36. - P. 15751-6. DOI:10.1073/pnas.1006172107

7 Hafner M, Landthaler M, Burger L, Khorshid M, Hausser J, Berninger P, Rothballer A, Ascano M Jr, Jungkamp AC, Munschauer M, Ulrich A, Wardle GS, Dewell S, Zavolan M, Tuschl T. Transcriptome-wide identification of RNA-binding protein and microRNA target sites by PAR-CLIP // Cell. - 2010. - Vol. 141, No. 1. - P.129-41. DOI:10.1016/j.cell.2010.03.009

8 Gaidatzis D, van Nimwegen E, Hausser J, Zavolan M. Inference of miRNA targets using evolutionary conservation and pathway analysis // BMC Bioinformatics. - 2007. - No.8. - P. 69. DOI:10.1186/1471-2105-8-69

9 Atambayeva S, Niyazova R, Ivashchenko A, Pyrkova A, Pinsky I, Akimniyazova A, Labeit S. The Binding sites of miR-619$5 p$ in the mRNAs of human and orthologous genes// BMC Genomics.- 2017.- Vol. 18, No. 428. DOI:10.1186/s12864-017-3811-6.

10 Matilla-Dueñas A. Machado-Joseph Disease and other Rare Spinocerebellar Ataxias. In: Ahmad S.I. (eds) Neurodegenerative Diseases // Advances in Experimental Medicine and Biology. - 2012. - Vol. 724. - P. 172-188. DOI: 10.1007/978-1-4614-0653$2 \_14$

11 Wang J, Dong L, Xu L, Chu ES, Chen Y, Shen J, et al. B cell CLL/lymphoma 6 member B inhibits hepatocellular carcinoma metastases in vitro and in mice // Cancer Lett. - 2014. - Vol. 355, No. 2. - P.192-200. DOI:10.1016/j.canlet.2014.08.025.

12 Wang W, Huang P, Wu P, et al. BCL6B expression in hepatocellular carcinoma and its efficacy in the inhibition of liver damage and fibrogenesis // Oncotarget. - 2015. - Vol. 6, No. 24. - P.20252-20265. DOI: 10.18632/oncotarget.3857

13 Thion MS, Tézenas du Montcel S, Golmard J-L, et al. CAG repeat size in Huntingtin alleles is associated with cancer prognosis // European Journal of Human Genetics. - 2016. - Vol. 24, No. 9. - P.1310-1315. Doi:10.1038/ejhg.2016.13

14 Harjes P, Wanker EE. (2003) The hunt for huntingtin function: interaction partners tell many different stories // Trends in Biochem Sci. - 2003. - Vol. 28, No. 8. - P. 425 - 433. DOI: 10.1016/S0968-0004(03)00168-3

15 Zhang G, Wang Z. MAGI1 inhibits cancer cell migration and invasion of hepatocellular carcinoma via regulating PTEN // Zhong Nan Da Xue Xue Bao Yi Xue Ban. - 2011. - Vol. 36, No. 5. - P. 381-385 DOI:10.3969/j.issn.1672-7347.2011.05.002

16 Bergerson RJ, Collier LS, Sarver AL, Been RA, Lugthart S, Diers, MD et al. An insertional mutagenesis screen identifies genes that cooperate with Mll-AF9 in a murine leukemogenesis model // Blood. - 2012.- Vol.119, No. 19. -P. $4512-4523$. DOI:10.1182/blood-2010-04-281428

17 Dejosez M, Krumenacker JS., Zitur LJ, Passeri M, Chu LF, Songyang, Z et.al. Ronin is essential for embryogenesis and the pluripotency of mouse ES cells // Cell. - 2008. - Vol. 133, No 7. - P. 1162-1174. DOI: 10.1016/j.cell.2008.05.047.

$18 \mathrm{http} / / /$ www.ncbi.nlm.nih.gov

$19 \mathrm{http} / / /$ mirbase.org

20 Ivashchenko A, Berillo O, Pyrkova A, Niyazova R. Binding Sites of miR-1273 Family on the mRNA of Target Genes // BioMed Res Int. - 2014. - Vol. 2014, 620530. DOI: 10.1155/2014/620530.

$21 \mathrm{Hu}$ S, Cao B, Zhang M, et al. Epigenetic silencing BCL6B induced colorectal cancer proliferation and metastasis by inhibiting P53 signaling // Am J Cancer Res. - 2015. - Vol. 5, No. 2, P. 651-662.

22 Zhang G, Liu T, Wang Z. Downregulation of MAGI1 associates with poor prognosis of hepatocellular carcinoma // J Invest Surg. - 2012. - Vol. 25, No. 2. - P. 93-9. DOI: 10.3109/08941939.2011.606875.

23 Pina C, May G, Soneji S, Hong D, Enver T. MLLT3 regulates early human erythroid and megakaryocytic cell fate // Cell Stem Cell. - 2008. - Vol. 2, No. 3. - P. 264-73. DOI: 10.1016/j.stem.2008.01.013. 
24 Grosveld G.C. MN1, a novel player in human AML // Blood Cells Mol Dis. - 2007. - Vol. 39, No. 3. -P. $336-339$. DOI:10.1016/j.bcmd.2007.06.009.

25 Pardee T.S. Overexpression of MN1 confers resistance to chemotherapy, accelerates leukemia onset, and suppresses p53 and Bim induction // PLoS One. - 2012. - Vol. 7, No. 8, e43185. DOI:10.1371/journal.pone.0043185

26 Parker JB, Palchaudhuri S, Yin H, Wei J, Chakravarti D. A transcriptional regulatory role of the THAP11-HCF-1 complex in colon cancer cell function // Mol Cell Biol. - 2012. - Vol. 32, No 9. - P. 1654-70. DOI: 10.1128/MCB.06033-11.

27 Bobori C. Molecular Genetics of Huntington's Disease // Adv Exp Med Biol. - 2014. - Vol. 822. - P. 59-65. DOI: 10.1007/9783-319-08927-0_9

28 Kong XZ, Yin RH, Ning HM, Zheng WW, Dong XM, Yang Y, Xu FF, Li JJ, Zhan YQ, Yu M, Ge CH, Zhang JH, Chen H, Li CY, Yang XM. Effects of THAP11 on erythroid differentiation and megakaryocytic differentiation of K562 cells // PLoS One. 2014. - Vol. 9, No. 3. - P. e91557. DOI:10.1371/journal.pone.0091557

29 Niyazova R, Berillo, O, Atambayeva S., Pyrkova A., Alybayeva A., Ivashchenko, A. miR-1322 binding sites in paralogous and orthologous genes// BioMed Res Int. - 2015. - Vol. 2015, No. 962637. DOI: 10.1155/2015/962637

30 Schnall-Levin M, Rissland OS, Johnston KW. Unusually effective miRNA targeting within repeat-rich coding regions of mammalian mRNAs // Genome Res. - 2011. - Vol. 21, No. 9. - P. 1395-1403. DOI: 10.1101/gr.121210.111 